\title{
Macroeconomic Determinants of Saudi Total Factor Productivity
}

\author{
Wael Mousa \\ Correspondence: Wael Mousa, Assistant Professor of Economics, Al Yamamah University, Kingdom of Saudi Arabia.
}

Received: November 6, 2017

Accepted: December 3, $2017 \quad$ Available online: December 11, 2017

doi:10.11114/aef.v5i1.2856

URL: https://doi.org/10.11114/aef.v5i1.2856

\begin{abstract}
Traditionally, labor productivity has been modelled as driven by capital accumulation, and the technology issue is exogenous. However, this model has been unable to sufficiently explain growth, and recent thinking on growth has given prominence to other factors such as technological advancement, human capital, and research and development. This has led to new growth models. This study employed the conventional growth accounting framework and aimed to estimate the total factor productivity in Saudi Arabia from 1970 to 2015. Additionally, it aimed to explore the macroeconomic determinants that affect total factor productivity. The results confirmed that economic stability, trade openness, and human factor development have positive impacts on total factor productivity. Interestingly, private credit by banks has a negative impact on Saudi total factor productivity. Negative relationships were also found between total factor productivity and the variables of population growth and government consumption.
\end{abstract}

Keywords: total factor productivity, economic growth, production

JEL Codes: C14, O47, and F43

\section{Introduction}

Insight on why some countries are richer than others, or why some countries are developing faster than others, requires information about the cross-sectional analysis and time series analysis for inputs and outputs, in relation to productivity. Average household income within the richest countries is 30 times that of the poorest countries; this income gap has doubled in the past 40 years (Tomas et al., 2001).

Lord Kelvin proclaimed over a century ago, "If you cannot measure it, you cannot improve it" (Suwardy, 2012). Therefore, exploring economic performance has posed an important challenge to researchers and academics over the last three decades. These efforts have been hamstrung by the paucity of reliable, consistent, and internationally comparable data. Some of the studies that have aimed to explore economic performance have focused on regional and country-level performance. The research literature shows these analyses to have employed three major approaches: 1) The most typical approach focuses on growth in real gross domestic product (GDP) per capita, which is considered as a proxy for the standard of living and economic performance. 2) Other studies have examined the extent of convergence achieved by the poorer nations and measured disparities in the global distribution of income (Theil \& Moss, 1999). 3) Finally, studies on the growth in real GDP have focused on productivity performance based on partial measures, such as output per person employed or per hour worked, and multi-factor productivity measures based on the concept of total factor productivity (TFP).

Among the factors that affect the determination of a country's output are the size of the labor force, capital stock, education, and government regulations. Any theory of economic growth has to make a choice on which of these factors to emphasize as a main source(s) for measuring economic progress over time or between countries. A growth accounting framework helps to segregate TFP from other sources of economic growth.

The main objectives of the present study are to estimate TFP and to explore the main determinants of economic growth in Saudi Arabia by embracing a wider perspective on economic productivity. There are relatively few studies that have aimed to estimate productivity growth in Saudi Arabia. This study adds to the existing estimates for Saudi Arabia by first estimating TFP through a conventional growth accounting process, by using the longest and most recent time series data available, and then establishing the macroeconomic determinants of TFP. Also, the time factor of this study plays an important role in achieving the goals of Saudi Vision 2030, a new economic plan announced in 2016, which focuses on increasing the competiveness of the Saudi economy and transforming productivity so as to double the GDP by 2030.

The structure of the paper is as follows. Section 2 presents an overview of the Saudi economy in the past and the future 
in light of Saudi Vision 2030. Section 3 discusses the methodology and briefly outlines the major sources of data and describes all the variables in the study. Empirical results are presented in Section 4, and the paper ends with concluding remarks.

\section{Saudi Economic Productivity at a Glance}

Saudi Arabia has one of the largest economies in the Middle East and North Africa, representing one-fourth of the GDP in this region. Since 2003, the Saudi economy has doubled, and according to international rankings its economy moved from $27^{\text {th }}$ in the world in 2003 to $19^{\text {th }}$ in 2014 (McKinsey Global Institute 2015). During the 2003-13 period, the government of Saudi Arabia has invested heavily in projects devoted to infrastructure, health, and education.

In recent decades, Saudi Arabia has witnessed an intense fluctuation in its real growth rate, specifically during the 1970s and 1980s (Figure 1). The highest annual growth rate, in 1973, was slightly higher than 24\%. In that year, the world witnessed the first oil shock as the price of oil rise from \$3 per barrel in the last quarter of 1973 to nearly $\$ 12$ in the first quarter of 1974. Annual growth rates during the 1970s, 1980s, 1990s, and from 2000 to 2015 have been 12.14\%, $-2.07 \%, 3.65 \%$, and $4.13 \%$, respectively. The compound annual growth rate over the whole period is $4.23 \%$.

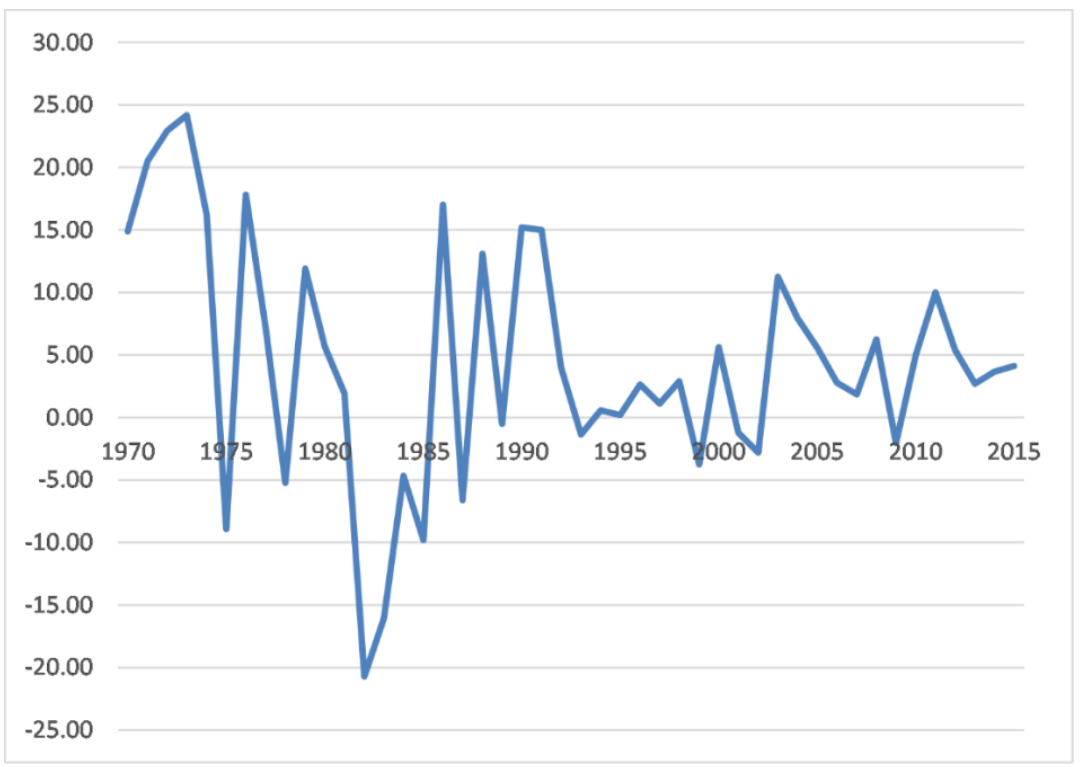

Figure 1. Annual real growth rate for Saudi Arabia

The correlation between the price of oil on the international markets and real GDP in Saudi Arabia from 1971 to 2015 is 0.5641, which means that the Saudi economy is very sensitive to oil prices (Figure 2). More than half of the fluctuations over the previous four decades are attributable to changes in oil prices. During this period of time, the real GDP per capita decreased from SAR124,722 in the 1970s to SAR 77,010 today (Figure 3).

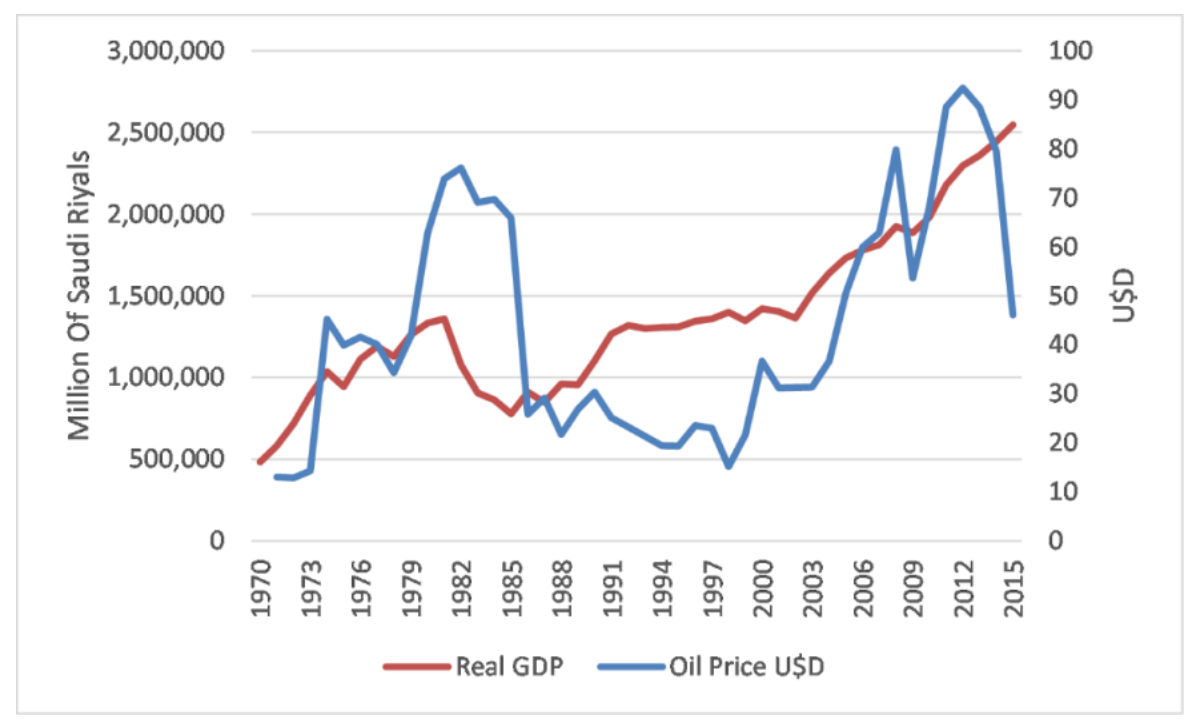

Figure 2. Real GDP and oil price 


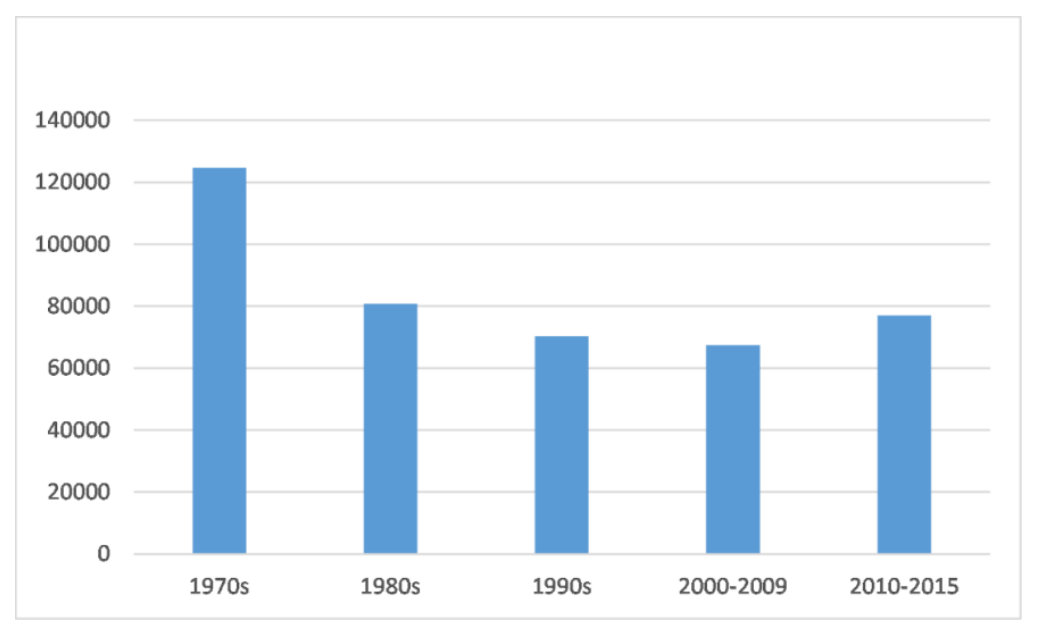

Figure 3. Real GDP per capita in Saudi Arabia

In 1981, Saudi Arabian university graduates numbered 4,273 at the bachelor's level and 369 at the postgraduate level; in that year the share of education in the general budget was $8.7 \%$ for all levels of education and $3.2 \%$ for higher education. By 2015, the number of graduates had increased significantly-154,596 at the bachelor's level and 18,741 for postgraduate studies - and outlays for education at all levels constituted $25 \%$ of the general budget. This reflects the role of education in the knowledge-based economy and in terms of the sustainability of human capital. There are also some major reform initiatives underway in the Saudi labor market, which will have a direct impact on market participants. Under these circumstances, lower oil prices and subsequent consequences for economic activity might present a challenge. However, the major education initiatives over the past decade are resulting in a better match of the skills of the young Saudi labor force, which is expected to counter the negative aspects.

\subsection{Saudi Vision 2030}

Saudi Vision 2030, which was announced at the beginning of the second quarter of 2016 by Deputy Crown Prince Mohammad bin Salman, is a plan to reduce the dependence of the Kingdom of Saudi Arabia (KSA) on oil and rely on other alternatives through diversifying its economy. According to the plan, the KSA can live without oil by 2020 even if the price of oil falls below $\$ 30$ per barrel. One of the important goals of this vision is to increase non-oil exports six fold, to increase the share of such exports within the Saudi GDP to 50\%, and to increase the share of small and medium-sized enterprises within the GDP to $35 \%$.

The plan is based on three themes: vibrant society, thriving economy, and ambitious nation. The three themes are inextricably intertwined in order to achieve the vision. The second theme focuses on creating a thriving economy that provides various opportunities to all Saudis by building educational systems to satisfy market needs; creating economic opportunities for entrepreneurs and businesses; developing investment tools to unlock the promising sectors and then diversify the Saudi economy and job creation; and finally improving the business environment to leverage the country's unique strategic location.

One belief at the root of Saudi Vision 2030 is that education will accelerate the Saudi economy and productivity in general. Among the targets of the plan are to respond to the shortage of educational institutions' outputs and the requirements of the labor market, develop public education, advise students about potential job opportunities, and to have at least five Saudi universities ranked among the top 200 universities in the world. Educational institutes play an important role in achieving this vision.

The importance of labor productivity is best captured by Nobel laureate Paul Krugman, who said that "Productivity isn't everything, but in the long run it is almost everything. A country's ability to improve its standard of living over time depends almost entirely on its ability to raise output per worker" (Krugman, 1994).

\section{Methodology}

\subsection{Aggregate Growth Accounting and TFP}

Growth accounting decomposes economic growth into components: changes in factor inputs and a residual that reflects technological progress and other elements. The importance of productivity changes in economic theory can be traced to the work of Solow (1956) on the neoclassical growth model that appeared in the 1950s. Despite the importance of the contribution of factor accumulation to output and real income expansion, the critical effect of TFP on growth has been widely accepted for quite some time. Empirical growth accounting uses the aggregate neoclassical production function 
to decompose the growth rate of aggregate output into the contributions of growth of measured inputs and improvements in TFP (Khan, 2006). Following the model of neoclassical production function, we assume that GDP can be expressed as a function of physical capital and human capital as:

$$
Y=A F(K, H)
$$

where $Y$ is GDP in constant prices, $A$ is an index of TFP, $K$ is gross domestic capital stock in constant prices, and $H$ is human-capital-adjusted labor input. $H$ is defined as:

$$
H=L * D * P * \operatorname{EXP}\left(\varphi^{*} S\right)
$$

where $L$ is the population, $D$ is the share of population aged 15-64, $P$ is the labor force participation rate, $S$ is mean years of schooling, and $\varphi$ is a parameter that measures the returns on education.

We consider the Cobb-Douglas production function with possibly non-constant returns to scale:

$$
F(K, L)=\left[K^{\alpha} H^{1-\alpha}\right]^{\gamma}
$$

where $\alpha$ is a parameter between 0 and 1 that measures the relative importance of capital, and $\gamma$ is a parameter that measures the extent of returns to scale. Reasonable values of $\alpha$ range from 0.3 (resulting in TFP growth of $1.6 \%$ a year) to 0.5 (resulting in TFP growth of just $0.3 \%$ a year). This is in accordance with assessments of the evidence both by growth-accounting practitioners (Collins \& Bosworth, 1996) and by econometricians (Ghosh \& Kraay, 2000; Aiyar \& Dalgaard, 2005). If $\gamma=1(\gamma>1)(\gamma<1)$, there are constant (increasing) (decreasing) returns to scale. Reasonable values of $\gamma$ range from 0.8 to 1.2 (Lanchovichina \& Gooptu, 2007). Constant elasticity of substitution (CES) is a property of some production functions. A neoclassical production function, CES arises in a particular type of aggregator function that combines two or more types of production inputs into an aggregate quantity. For the CES production function, production technology has a constant percentage change in $\mathrm{L}$ and $\mathrm{K}$ proportions due to percentage change in the marginal rate of technical substitution. The two-factor production function (labor and capital) was introduced by Solow (1956) and then updated by Arrow, Chenery, Minhas, and Solow (1961).

$$
\begin{gathered}
Y=A *\left(\alpha * K^{\rho}+(1-\alpha) L^{\rho}\right)^{\frac{1}{\rho}} \\
\rho=\frac{S-1}{S} \\
S=\frac{1}{1-\rho}
\end{gathered}
$$

In equation (4), $\rho$ is equal to 1,0 , or negative. When it is equal to 1 , it exhibits a perfect substitution function; when it is equal to 0, it represents a Cub-Douglas function; and when it is negative, it exhibits a Leontief perfect complements function. In equation (5), $\mathrm{S}$ refers to the elasticity of substitution.

Changes in A (TFP) indicate shifts in the relationship between aggregate inputs and outputs. Changes in TFP in this aggregate model are assumed to be caused by changes in the level of technology and changes in efficiency and/or in the scale of operations of the country.

$$
\Delta(A)=\Delta(Y)-\gamma[\alpha \Delta(K)+(1-\alpha) \Delta(H)]
$$

From equation (7), growth in TFP can be written as growth in output less the weighted average of growth in inputs.

\subsection{Data}

Data are extracted from two main sources: the General Authority for Statistics in Saudi Arabia and the World Bank.

$Y$ represents real GDP in constant SAR (indexed to 2010); $L$ is the population measured as a total at the end of each year; and $K$ is capital stock, which is constructed using the perpetual inventory method (Nehru \& Dhareshwar, 1993). In this study, we estimate the capital stock, which requires information on the depreciation rate $(\delta)$ and gross capital formation in 2010 SAR prices.

Although capital stock is very seldom directly available (Collins \& Bosworth, 1996), there are various methods to estimate the initial capital-output ratio $\left(k y_{0}\right)$. For most developing countries, reasonable values range between 1 and 2 . In this study, we assume the value of this ratio as 1.5 . The perpetual inventory method produces annual estimates of 
gross and net capital stock at constant and current prices by accumulating past flows of expenditure on investments (Ball, Butault, \& Nehring, 2001). Reasonable values for the depreciation rate range from 0.04 to 0.08 (Ghosh \& Kraay, 2000; Ozyurt, 2009). In this study, we follow previous studies and use this ratio as 0.04The capital stock in 1988 is $\left(k y_{0}\right)$ times $Y$ in 1988. For subsequent years, the capital stock is obtained using the following formula:

$$
K_{t}=(1-\delta) K_{t-1}+I_{t}
$$

The share of the population aged 15-64 and the labor force participation rate are available from the World Bank database. Data on the mean years of education are available from the UNESCO database. The parameter $(\varphi)$, which measures the returns on education (the percentage increase in worker productivity due to an additional year of education) is assumed to be 0.1 or $10 \%$ (Krueger, 2002).

\section{Results}

\subsection{Estimation of TFP}

The results of the growth accounting exercise are obtained as follows.

Table 1. TFP estimation with the growth accounting approach —empirical results for selected periods

\begin{tabular}{|c|c|c|c|c|}
\hline Periods & $\Delta Y$ & $\Delta K$ & $\Delta \mathbf{H}$ & $\Delta$ TFP \\
\hline 1970-2015 & $2.4 \%$ & $3.5 \%$ & $6.3 \%$ & $-2.9 \%$ \\
\hline 1970-1979 & $9.9 \%$ & $9.0 \%$ & $7.1 \%$ & $2.2 \%$ \\
\hline 1980-1989 & $-4.1 \%$ & $2.4 \%$ & $8.6 \%$ & $-10.5 \%$ \\
\hline 1990-1999 & $1.7 \%$ & $2.0 \%$ & $4.8 \%$ & $-2.2 \%$ \\
\hline $2000-2015$ & 4.2 & $3.9 \%$ & $6.1 \%$ & $-1.2 \%$ \\
\hline
\end{tabular}

Source: Author calculations

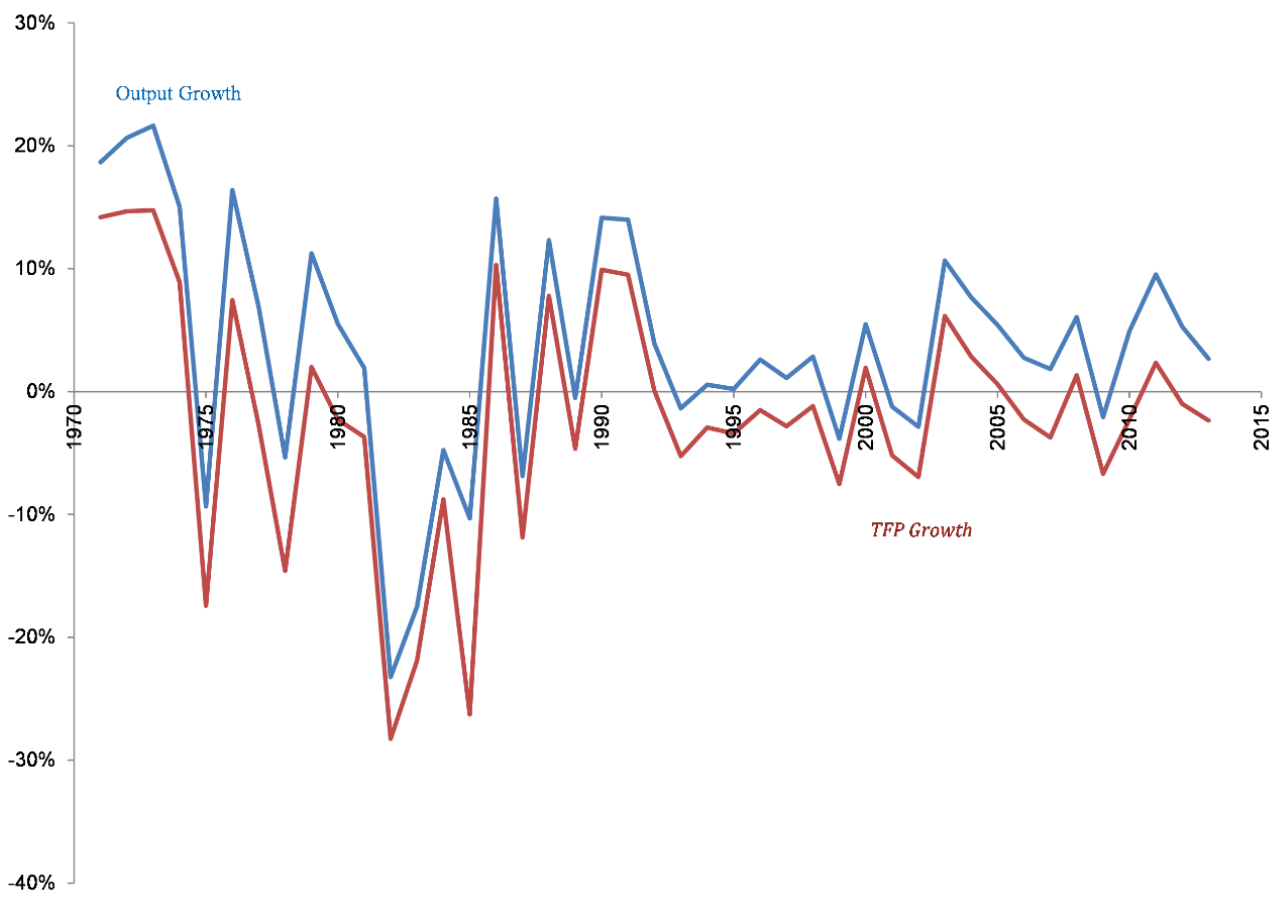

Figure 4. GDP growth and estimated productivity growth

Figure 4 presents the relation between GDP and TFP growth in graphical form. It is observed that the growth of GDP and TFP followed identical behavior throughout the study period. It reflects the pattern that if TFP rises, GDP growth follows this momentum, and vice versa. Specifically, during the 1970s, a $2.2 \%$ growth rate of TFP was followed by a 9.9\% higher GDP growth rate (the highest rate during the study period). During the 1980s, TFP growth dipped to $-10.5 \%$, and it pulled GDP growth down to $-4.1 \%$, obviously much lower than the growth of GDP in the preceding decade. However, in the next decade of the 1990s, the $-2.2 \%$ growth of TFP represented a significant improvement over the preceding decade. Similarly, GDP growth took momentum and increased by $1.7 \%$ during this period. Finally, from 2000 to 2015, an improvement in TFP growth of $-1.2 \%$ resulted in 4.2\% relatively higher GDP growth during the 1990 s. 
From the above discussion, we conclude that TFP growth and GDP growth patterns are examples of a high degree of correlation, which is $97.1 \%$.

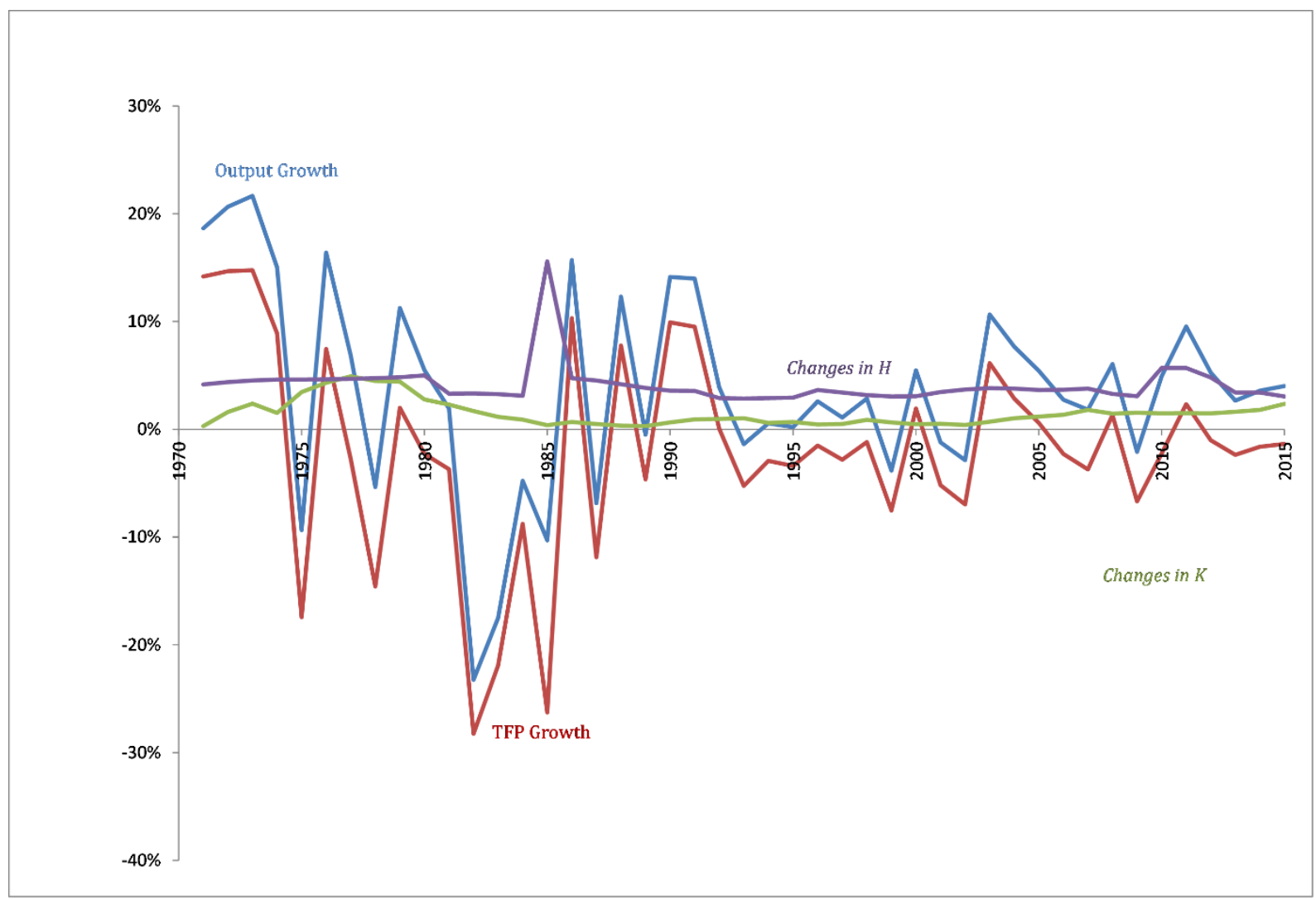

Figure 5. Real GDP growth explained by factors of production

\subsection{Macroeconomic Determinants and TFP}

We employ the basic empirical framework that is based on the determinants of economic growth. The model is presented in the following formula:

$$
\begin{gathered}
\text { TFP } P_{t}=\beta_{0}+\beta_{1}[\text { Macroeconomic Stability }]+\beta_{2}[\text { Openness of the Economy }]+\beta_{3}[\text { Human Sector Development }] \\
+\beta_{4}[\text { Fin.Sector Development }]+\beta_{5}[\text { Control Variables }]+\mu_{t}
\end{gathered}
$$

Macroeconomic stability can be defined as a low and stable inflation rate, and openness of the economy can be assessed by the ratio of the sum of imports and exports to GDP. Human sector development can be judged through the enrollment in tertiary education. Finally, financial sector development can be determined by domestic credit to the private sector by banks. In addition to these macroeconomic determinants, some control variables are added to the model, e.g., population and government consumption.

The role of inflation in economic growth is controversial among economists. This study used inflation as an explanatory variable in the model to indicate economic stability. Economic stability is hypothesized as necessary for the growth of TFP. The rationale behind this is that inflation stimulates economic growth by increasing employment or increasing the number of hours of work. From this point of view, we expect a positive sign in this model.

The study used the sum of imports and exports as a percentage of GDP to measure the trade openness and find its relation to economic growth and the increase in TFP. Generally, trade openness has a favorable impact on economic growth through increasing the productivity of the economy. The rationale here is that more trade openness will lead to better accessibility to inexpensive intermediate goods from other countries, and increase the technological advance in production.

To measure the human sector development, and because of the lack of consistent data for the study period, the study employed enrollment in tertiary education as an indicator. The study expects a positive sign for this variable on economic growth and growth in TFP.

The study employed domestic credit to the private sector by banks as an indicator of financial development that may 
influence economic growth and TFP. Studies in the literature show ambiguous results for the effects of domestic credit to the private sector on TFP. Generally, there are two approaches: quantity and quality. Under the quantity approach, the financial sector can improve capital accumulation when it can induce private savings or adopt new technologies that will increase the supply of funds. In contrast, the quality approach examines the importance of financial institutions to increase technological innovations. The rate of technological innovation becomes faster when the financial sector reveals the rewards to engaging in such innovations, relative to continuing in traditional practices. Private credit only enhances economic growth; it increases the economic productivity of firms and TFP for the overall economy. In general, we expect a positive sign for this parameter.

The study employed population as a control variable that may positively affect the pace of economic growth. We cannot establish a strong positive relationship between population growth and TFP. We expect a negative impact of population growth on TFP, since the idle labor accumulation is also a factor that causes a downward pressure on TFP.

Finally, the study employed government consumption as a percentage of GDP to observe its impact on TFP. Several studies have examined the impact of government consumption on economic growth, but studies have indicated that the government's role can either foster or hinder economic growth (Ranis, 1989). In this study, we expect a positive impact of government consumption on TFP, as provision of public goods would enhance the overall productivity of labor by diverting resources from nonproductive uses.

The empirical results (Table 2) show that inflation, trade openness, and enrollments in tertiary education have positive signs. This indicates that economic stability, openness of the Saudi economy, and human sector development have a positive impact on TFP, i.e., if inflation increases by $2 \%$, TFP will increase by $1.65 \%$; an increase in trade openness of $1 \%$ will increase TFP by $0.37 \%$; and an increase in enrolment in tertiary education of $10 \%$ will increase TFP by $0.17 \%$. Interestingly, the results show a negative association between TFP and credit to the private sector by banks, population growth, and government consumption, i.e., increased domestic credit by banks to the private sector by $1 \%$ will decrease TFP by $1.5 \%$, and a $1 \%$ increase in government consumption will decrease TFP by $2.2 \%$. Population has a very small negative effect on TFP; an increase in the Saudi Arabian population by one thousand will decrease TFP by 5\% All the variables included in the regression analysis are significant at 5\% except for trade openness, at $10 \%$.

Table 2. Macro determinants of total factor productivity

\begin{tabular}{|c|c|c|}
\hline Variables & Description & $\begin{array}{c}\text { Simple } \\
\text { pooled } \\
\text { OLS }\end{array}$ \\
\hline Inflation & Consumer price index & $\begin{array}{c}0.826301 \\
0.826301 * * \\
(0.320066)\end{array}$ \\
\hline Trade openness & Sum of exports and imports as $\%$ of GDP & $\begin{array}{l}0.366970 * \\
(0.184276)\end{array}$ \\
\hline Employment tertiary education & $\begin{array}{l}\text { Enrolment in tertiary education per 100,000 inhabitants, both } \\
\text { sexes }\end{array}$ & $\begin{array}{r}0.016666 * * * \\
(0.005584)\end{array}$ \\
\hline $\begin{array}{l}\text { Domestic credit by banks to private } \\
\text { sector }\end{array}$ & Domestic credit to private sector by banks as $\%$ of GDP & $\begin{array}{r}-1.461485^{* *} \\
(0.668692)\end{array}$ \\
\hline Population & Number of population of Saudi Arabia & $\begin{array}{c}-0.000005^{* * *} \\
(0.000001)\end{array}$ \\
\hline Government consumption & General government final consumption as $\%$ of GDP & $\begin{array}{c}-2.169994 * * * \\
(0.434868)\end{array}$ \\
\hline Constant & & $\begin{array}{c}219.5879 \\
(23.10980)\end{array}$ \\
\hline $\begin{array}{l}\text { Observations } \\
\text { R-squared }\end{array}$ & & $\begin{array}{c}43 \\
0.954095\end{array}$ \\
\hline
\end{tabular}

Notes: Standard errors in parentheses. $* * * \mathrm{p}<0.01, * * \mathrm{p}<0.05, * \mathrm{p}<0.1$

\section{Conclusion}

Following the conclusions of Griliches and Jorgenson (1967) and Christenes and Jorgenson (1970), errors in measurement can lead to substantial errors in the estimated residuals. When drawing conclusions from Solow's residual model, several things have to be noted. First is the size of the shadow economy, which is not included in real GDP. Second is labor force quality; this study adjusted the human capital according to the number of school years attended, but we cannot confirm that each year of studies will have the same impact of increasing the productivity.

These caveats notwithstanding, this study estimated the total factor productivity of the Saudi economy and applied a 
multiple regression model to identify macroeconomic determinants that influence TFP, for the relatively long time period of 1970-2015.

The economic policy maker can improve TFP in the long run by fostering a lower rate of inflation, which would have positive effects on TFP, and by implementing policies that promote trade openness and higher education. Additionally, there is a need to rationalize government consumption and to subsidize innovation and new technology through more loans at lower interest rates.

The results confirm that economic stability, trade openness, and human factor development have a positive impact on the total factor productivity of Saudi Arabia. Interestingly, private credit by banks has a negative impact on Saudi TFP, as do population growth and government consumption. Encouraging high school students to continue with higher education will bring some TFP improvement. On the other hand, domestic credit to the private sector by banks has a negative relation with TFP. We recommend that financial policy makers who are involved with commercial credit encourage Saudi Arabian banks to focus on lending to elements of the business sector that adopt new technologies. Finally, with regard to government consumption and population, we recommend that economic policy makers maintain rationality over government expenditures and make improvements in access to family planning throughout Saudi Arabia.

\section{References}

Ball, V. E., Butault, J. P., \& Nehring, R. (2001). U.S. Agriculture, 1960-96: A Multilateral Comparison of Total Factor Productivity. Washington, D.C.: U.S. Dept. of Agriculture. http://purl.access.gpo.gov/GPO/LPS18385

Christenes, L. R., \& Jorgenson, D. W. (1970). The U.S. Real Product and Real Factor Input, 1927-1967. Review of Income and Wealth, 16(1), 19-50. https://doi.org/10.1111/j.1475-4991.1970.tb00695.x

Collins, S. M., \& Bosworth, B. P. (1996). Economic Growth in East Asia: Accumulation versus Assimilation. Brookings Papers on Economic Activity, 135-203. https://doi.org/10.2307/2534621

Griliches, Z., \& Jorgenson, D. (1967). The Explanation of Productivity Change. The Review of Economic Studies, 34(3), 249-284. https://doi.org/10.2307/2296675

Khan, S. U. (2006). Macro Determinants of Total Factor Productivity in Pakistan. SBP Working Paper Series (State Bank of Pakistan) 10: 9.

Krueger, A. B. (2002). Inequality, Too Much of a Good Thing. CEPS Working Paper (Princeton University and NBER ) 87.

Krugman, P. (1994). The Myth of Asia's Miracle. FOREIGN AFFAIRS, 78(6), 62-87. https://doi.org/10.2307/20046929

Lanchovichina, E., \& Sudarshan, G. (2007). Growth Diagnostics for a Resource-Rich Transition Economy: The Case of Mongolia. Policy Research Working Paper (World Bank) 4396. https://doi.org/10.1596/1813-9450-4396

McKinsey Global Institute. (2015). Saudi Arabia Beyond Oil: The Investment and Productivity Transformation. Executive Summary, McKinsey \& Company.

Nehru, V., \& Dhareshwar, A. (1993). A New Database on Physical Capital Stock: Source, Methodology and Result. Economic Analysis Review, 8(1), 39-59. http://www.rae-ear.org/index.php/rae/article/view/202/462.

Ranis, G. (1989). The Role of Institutions in Transition Growth: The East Asian Newly Industrialized Countries. World Development, 17(9), 1443-1453. https://doi.org/10.1016/0305-750X(89)90085-5

Suwardy, T. (2012). Productivity Measurements for Accounting Functions. In Accounting \& Productivity: Answering the Big, edited by Themin Suwardy and Gary Pan, 34-42. Singapore.: CPA Australia Ltd. http://ink.library.smu.edu.sg/cgi/viewcontent.cgi?article=1926\&context=soa_research.

Theil, H., \& Charles, B. M. (1999). Note The measurement of inequality by components of total expenditure. Empirical Economics (Springer), 24(3), 559-561. https://doi.org/10.1007/s001810050072

\section{Copyrights}

Copyright for this article is retained by the author(s), with first publication rights granted to the journal.

This is an open-access article distributed under the terms and conditions of the Creative Commons Attribution license which permits unrestricted use, distribution, and reproduction in any medium, provided the original work is properly cited. 